\begin{tabular}{|c|c|c|c|c|c|c|}
\hline \multirow{4}{*}{ Impact Factor: } & ISRA (India) & $=3.117$ & SIS (USA) & $=0.912$ & ICV (Poland) & $=6.630$ \\
\hline & ISI (Dubai, UAE & $=0.829$ & РИНЦ (Russia) & $=0.156$ & PIF (India) & $=1.940$ \\
\hline & GIF (Australia) & $=0.564$ & ESJI (KZ) & $=8.716$ & IBI (India) & $=4.260$ \\
\hline & JIF & $=1.500$ & SJIF (Morocco) & $=5.667$ & OAJI (USA) & $=0.350$ \\
\hline
\end{tabular}

\section{SOI: $\underline{1.1 / \mathrm{TAS}}$ DOI: $\underline{10.15863 / \mathrm{TAS}}$ \\ International Scientific Journal Theoretical \& Applied Science}

p-ISSN: 2308-4944 (print) e-ISSN: 2409-0085 (online)

Year: 2019 Issue: 05 Volume: 73

Published: $30.05 .2019 \quad \underline{\text { http://T-Science.org }}$
QR - Issue
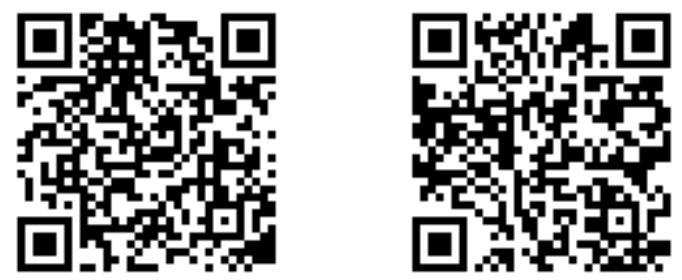

Furkat Raxmatovich Mirzaev

Ph.D, docent of Tashkent state pedagogical university, Tashkent city, Republic of Uzbekistan

SECTION 31. Economic research, finance,

innovation, risk management.

\title{
FOREIGN EXPERIENCE IN THE PREPARATION OF A SPORTS MANAGER: IN CASE OF RUSSIA
}

Abstract: The questions of the need for training and advanced training of sports managers are analyzed, the relevance of their work in the modern world is reflected. A special, specific role in the formation of new economic and cultural relations is played by specialists and teachers of physical education. The features of training sports managers abroad are considered.

Key words: sports manager, sports management, sports organization, manager, healthy lifestyle.

Language: English

Citation: Mirzaev, F. R. (2019). Foreign experience in the preparation of a sports manager: in case of Russia. ISJ Theoretical \& Applied Science, 05 (73), 439-444.

Soi: http://s-o-i.org/1.1/TAS-05-73-65 Doi: rostef https://dx.doi.org/10.15863/TAS.2019.05.73.65

\section{Introduction}

The sphere of physical culture and sports is not only the most important area of society's activity [1], but also a branch of the economy with special working conditions. Issues of high-quality training of managers of sports organizations at the moment not only have not lost their relevance, but, in our opinion, have become more popular. Successful performances of Russian athletes in the world arenas reflect not only the professionalism of their coaches, but also the professional work of sports managers.

Some training programs for sports managers are a synthesis of Russian and foreign experience. Higher education institutions play a leading role in the training of specialists with a high level of competence for the cultural, social and economic spheres of our state. This applies to all graduates, but to a greater extent to graduates of pedagogical specialties, who later become the main actors in the educational process, taking part in major transformations and updates of society [2]. The leading role in the construction and formation of modern economic and cultural relations remains with the specialists teachers of physical culture.

\section{Literature review}

The national management-education system actively absorbs the experience of countries with a free market economy in training managers (T.E. Kruglova, 2009; VN Zuev, 2006). Thus, B. Pitts and
D. Stotlar (2002) define that the scope of sports management is "people, activities and organizations involved in the production, promotion or organization of any type of product related to sports, fitness or physical recreation" [13]. This definition includes a large selection of career paths for a modern sports manager.

Currently, sports managers in our country are faced with the problems of socio-economic transformation, the transition from a centralized system of sports management to a decentralized one (V.N. Zuev, 2006; S. E. Voronin, 2002, S. S. Filippov, 2006), organizations in terms of partial or full selfsufficiency (V.V. Aleshin, 2000; V.V. Galkin, 2006), restructuring of organizational methods in a market economy (A.V. Minaev, 2003), pushing away from the planned management system of physical culture sport movement (L.V. Toropov, 1995).

Currently, one of the main tasks of higher education is to identify and apply such innovative training technology that ensures the development of a person's ability to self-improve, be creative, adapt to working conditions and constantly update their professional knowledge, be ready to work effectively. rapidly changing conditions, which is implemented in the framework of the competent approach [2].

Competence approach in the generally accepted interpretation implies the integration of theoretical and practical training in the process of education, i.e. the formation of not only the "knowledge", but also 


\begin{tabular}{|c|c|c|c|c|c|c|}
\hline \multirow{4}{*}{ Impact Factor: } & ISRA (India) & $=3.117$ & SIS (USA) & $=0.912$ & ICV (Poland) & $=6.630$ \\
\hline & ISI (Dubai, UAI & $=0.829$ & РИНЦ (Russia & $=0.156$ & PIF (India) & $=1.940$ \\
\hline & GIF (Australia) & $=0.564$ & ESJI (KZ) & $=8.716$ & IBI (India) & $=4.260$ \\
\hline & JIF & $=1.500$ & SJIF (Morocco & $=5.667$ & OAJI (USA) & $=0.350$ \\
\hline
\end{tabular}

the personal component, which includes the emotional-value and operational basis of the regulation of activity, ensuring the graduate's adaptation to the labor market [12].

The need to integrate a competence-based approach into the education system is determined by the pan-European and global trend of integration, the globalization of the world economy, and the changing educational paradigm to the personality-oriented one that has occurred in the last decade. The definition of the productive side of education through the operationalization of the category of "competence" is the conceptual basis for the transformation of modern domestic universities, defined as the competence approach [12].

\section{Preparing sport managers in Russia}

The system of existing socio-economic relations in Russia has undergone major changes in recent years; the structure of society, value orientations, consumer behavior $[2,8]$ significantly change. The economic transformations carried out in the country are not always carried out consistently and are contradictory. All this has a negative impact on health, duration and lifestyle, behavioral stereotype of Russians.

Today, out of 10 school graduates, 7 are unsuitable for military service for health reasons. According to 2014, the average life expectancy for men is about 62 years. There is a high mortality rate at working age among men from 18 to 60 years old twice as often as women. The reasons for this negative state of affairs are well known: insufficient physical activity of the country's population, stress, the presence of bad habits in the form of alcohol abuse, drug use and smoking [9].

The role of physical culture in the formation of knowledge, the inculcation of healthy lifestyle skills and the adoption of a healthy lifestyle, the formation of personal physical culture at the present stage of development of society is greatly increasing.

In order to reverse the current negative trend in the country, it is necessary to adopt legislative and regulatory documents, to carry out effective work on the introduction of physical culture in the constituent entities of the Russian Federation.

Today, the manager's profession is one of the most sought-after and most popular in Russia, and interest in sports management is constantly increasing, at the end of the 19th century. in Europe and the United States as a result of the widespread and active promotion of a healthy lifestyle among the population and the mass hobby for sports appeared the profession of a sports manager [8]. In Russia, sports management is in its infancy. The All-Russian public organization "Federation of Sport Managers of Russia" was formed, which brought together management specialists in the sports industry.
In order not to be distracted from the training and competitive process, foreign athletes of international level enter into contracts with agents, managers and other specialists who make up his team and take on all administrative, organizational, economic issues, and often deal with the personal affairs of an athlete. It is these people who decide on the performances of the athlete, on communication with the media, interviews, on the conclusion of contracts with sponsors, etc. Often, income managers exceed the fees of athletes, this profession has become one of the most prestigious.

Sports managers often became former athletes and coaches who knew the whole process from the inside and represented it as a whole, they received the necessary managerial skills in economics departments and university courses. Later, independent educational institutions appeared in Europe that specialized in training professional sports managers [7]. The specifics of the sports industry as an economic sector determine the specifics of training sports managers [3].

Modern education in sports management reflects the entire spectrum of this industry: "sports tourism", "fitness management", "sports goods industry" and "sport administration", "sports marketing" and many other specialty areas offered by the best educational centers in the world. International hospitality schools in many countries offer a specialization in sports management. This fully demonstrates the specifics of the development of sports abroad, where a sports manager should understand the basics of the hospitality industry, since the sports industry is focused on providing services and the interests of the viewer.

All main disciplines in educational institutions of such a profile are common to both programs, of course, there are also subjects with specialization. Specialties for which one can study in educational institutions vary and depend on both the profile of the educational institution and the country in which it is planned to study sports management $[1,6]$.

Russian professional and student sports are developing today according to the American model (O. Matytsin, 2008). Years of experience in the development of the sports industry in a market economy, as well as theoretical and practical experience in the preparation of sports managers abroad is, in a sense, a guideline for creating a national school of sports management. The study of the competence of existing sports managers abroad will reveal the features of modern training in the university of Russian sports managers at the present stage of development of the national sports movement.

We have conducted a study of the competencies of a sports manager at the professional football club Vancouver Whitecaps FC, Canada. The survey involved 12 people, of whom 10 managers and 2 directors of the club. The experience of respondents in 


\begin{tabular}{|c|c|c|c|c|c|c|}
\hline \multirow{4}{*}{ Impact Factor: } & ISRA (India) & $=3.117$ & SIS (USA) & $=0.912$ & ICV (Poland) & $=6.630$ \\
\hline & ISI (Dubai, UAI & $=0.829$ & РИНЦ (Russia & $=0.156$ & PIF (India) & $=1.940$ \\
\hline & GIF (Australia) & $=0.564$ & ESJI (KZ) & $=8.716$ & IBI (India) & $=4.260$ \\
\hline & JIF & $=1.500$ & SJIF (Morocco & $=5.667$ & OAJI (USA) & $=0.350$ \\
\hline
\end{tabular}

the sports industry in various positions varies in the following ranges: from 6 months to a year (3 respondents); 2-4 years (5 respondents); 5-7 years (4 respondents). An analysis of the previous positions of the respondents shows that they had experience in areas other than sports, and only after that got a job in a professional club. Only 2 respondents have education in the field of sports management, the rest have education in the widest specialties.

The questionnaire questions were aimed at identifying the features of training a sports manager abroad, determining the forms of training managers the club, identifying the formation of professional competencies, determining the mobility of a specialist in related fields, as well as identifying key competencies, according to sports managers.

In the process of questioning, managers indicated, in descending order, key competencies for a sports manager, using the list of 22 core competencies required for a successful graduate's career in the 21 st century [14, p.61]. Thus, in the list of key competences in descending order, managers indicated communicative competence (oral and written); interpersonal relationships; teamwork; professional ethics; organizational qualities; honesty / decency; flexibility / adaptability; orientation to the study of details and details; motivation / initiative; self-confidence; analytical competence; personal qualities (friendliness, sociability); leadership skills; business / occupational risk; ability to self-education; ability to work in constantly changing working conditions; computer skills; creativity / creativity; knowledge of languages; nurture \politeness; sense of humor / stress tolerance; high performance.

Thus, managers have pointed out the need and importance of those categories for the education of which education can be directed within the framework of the competence approach, which is reflected in the works of many scientists. [14-15]

The results of the other part of the questionnaire showed that the club's sports manager should be ready for intense and varied content $(100 \%)$; be ready to show leadership skills (92\%); show initiative (92\%); be able to make quick decisions in a difficult situation ( $83 \%$ ); be able to adapt to new working conditions due to globalization (83\%); constantly improve their potential for effective work in changing conditions (75\%); make decisions based on personal opinion (72\%); periodically adapt to new organization methods at work $(67 \%)$; periodically use innovative solutions $(58 \%)$; periodically face changes in socioeconomic conditions $(50 \%)$; to face several times a year with the impact of socio-economic changes on working conditions (50\%); often refer to information about innovations in their field of activity (50\%); often isolate problems and look for solutions to their own $(50 \%)$; often use the skills of fast information retrieval using technical means $(50 \%)$; be ready for heavy adaptation in a new workplace $(33 \%)$; often organize the work of other people to increase efficiency (33\%); often control their own work and the work of other people to achieve compliance with the objectives of the work and the result (33\%). Managers also indicated that the formation of a world view and professional culture is necessary for a sports manager $(92 \%)$

In assessing the mobility of a sports manager for positions within the organization, a gap was revealed in the assessment of their own professional competence. Thus, only $17 \%$ of respondents indicated that their competence allows them to carry out professional activities in the field of finance and accounting of the organization; $25 \%$ in the field of sports law. At the same time, there was a high assessment of their own competence in the field of sports sales, management of a sporting event and sports sponsorship - 67\%, and in the field of marketing (communication \RYa \work with the media) 92\% indicated their high competence. When answering questioning questions and interviewing, managers pointed to the frequent occurrence of work situations in which it is necessary to use, among others, knowledge of finance and legal issues. At the same time, the participants of the survey indicated that they see opportunities for professional advancement not only in their department and often pointed to work in related fields of sports management. Considering the emphasis on training a broad specialist in the field of sports management at the university, as well as on increasing the mobility of a specialist in a chosen professional activity, more time should be spent on acquiring competence in the field of finance and legal issues of a sports organization, as well as expanding the professional horizons in other types activities.

In evaluating options for improving their own professional competence, managers indicated a study on the Internet - 100\%; refresher courses - 75\%; special magazines, trainings, public speaking at meetings - 50\%; professional internships $42 \%$ (where they also indicated the high importance of this criterion) and communication with industry colleagues - $25 \%$. It can be concluded that when preparing in higher education institutions, specialists need to be given information on ways to improve their skills through participation in professional conferences and meetings, as well as opportunities for internships (provided for and not covered by the curriculum) and volunteer participation in the field of professional activity such as for example, volunteer participation in the organization of a sporting event.

The results of the survey showed that the modern specialist in the field of sports management is required to manifest developed personal qualities in a constantly changing professional environment. Training a sports manager should manifest itself not only in the transfer of knowledge, but also contain the requirements for the development of professional competencies, the ability to adapt to the changing 


\begin{tabular}{|c|c|c|c|c|c|c|}
\hline \multirow{4}{*}{ Impact Factor: } & ISRA (India) & $=3.117$ & SIS (USA) & $=0.912$ & ICV (Poland) & $=6.630$ \\
\hline & ISI (Dubai, UAI & $=0.829$ & РИНЦ (Russia & $=0.156$ & PIF (India) & $=1.940$ \\
\hline & GIF (Australia) & $=0.564$ & ESJI (KZ) & $=8.716$ & IBI (India) & $=4.260$ \\
\hline & JIF & $=1.500$ & SJIF (Morocco & $=5.667$ & OAJI (USA) & $=0.350$ \\
\hline
\end{tabular}

conditions of the professional environment, and the willingness to increase one's professional potential.

According to the results of the research, it can be said that the nature of the work of a sports manager determines the requirements for the manifestation of high competence in such activities as: communicative, informational, analytical, organizational, managerial. Such competences are based on the effective manifestation of diverse personal qualities in a constantly changing professional environment, which greatly affect the outcome of the professional club.

Using the method of observation included, we evaluated the work of sports managers in the PFC Vancouver Whitecaps FC, Canada. Thus, the work of managers is distinguished by the following characteristics: unexpressed

hierarchy of interpersonal relations between the head and the subordinate; frequent use of methods of motivation of employees of the club (action "on the winner", team building events, joint celebrations, etc.); there is practically no control by the directors over the course of work, but high control over the result, which gives managers autonomy and responsibility in decision making; focus on active interaction within the department through internal events (daily creative meetings, monthly joint events); competition within the department is welcomed; setting personal goals for each employee and striving to create a friendly atmosphere between employees and the integrity of the team.

\section{Preparing sport managers in Europe}

The continuing growth of the sports industry and interest in it from the private sector and various institutions puts additional demands on the quality of training of sports managers abroad. The increasing interaction of sports and business at all levels of sports relations in rapidly changing conditions requires the sports manager to comply with environmental requirements and to demonstrate the ability to most universally use and apply the knowledge and skills obtained, in which the success of the subject's professional activity is natural. The use of advanced foreign theories of sports manager training in conjunction with the adaptation of the competencebased approach to modern education will determine the basis for the creation of a national school of sports management.

In foreign publications, it is noted that the future generation of sports managers will face the problems of technology development, sports ethics, globalization and social responsibility [5, C.24]. It is important to correctly navigate the focus of methodological issues and general practical problems of management in order to best implement the training of sports management personnel [10].

In Switzerland, training is conducted in the direction of "Event management and management of the sport and entertainment industry", in France in international sports management or management of sports organizations. In the UK, you can complete the universal specialization "Management in Sport", and in the United States of America, you can choose a whole range of managerial specialties, including individual sports.

Modern sports managers are distinguished by universal knowledge and high qualification; they possess knowledge of innovative technologies, new ideas and values, All this gives them a chance for career growth and successful business. The sports industry is developing rapidly, and schools and faculties of educational institutions are responsive to market demands. Future sports managers study a wide range of traditional "managerial" disciplines, as well as a range of specialized subjects, such as product policies and pricing in sports, the marketing strategy of a sports organization, sports event marketing, sports branding, distribution and sale of sports products and much more [6]. A graduate of such a foreign university can confidently occupy a senior position in various areas of the sports industry: hospitality companies, specialized PR and event agencies, fitness clubs, sports clubs, sports schools, professional associations and federations, and sports complexes.

In Germany, the training of certified sports managers can be characterized by highlighting the following features and main features. Representatives of the German school, engaged in training specialists in the field of sports, believe that because of the constant attention to sports due to the economic interests of society, the importance of sports for the nation as a whole, the inevitability of transformation processes affecting not only professional participants - athletes and their coaches - everything more obvious. The changes should also affect all professional managers and economists who know how it is most expedient to conduct financial and economic activities in physical education and sports organizations [5].

Produced specialists are sharks in the world of sports business, who are fluent in issues of financing, planning, organization, sponsorship and patronage and other issues necessary for organizations of physical culture and sports activities of various forms of ownership and scale.

As for the training of sports professionals in Canada, the main feature here is the use of a unified training system, regardless of basic education and further desire to continue training. Special training programs on sports management have been created and tested, which are taught in a differentiated form at specialized universities and colleges in the country.

Considering the existing practice in the Russian scientific community on the issues of advanced training of all heads of organizations at various levels, we can, unfortunately, state the existence of problems in this matter. The problems of not taking into account the differentiated nature of the activities of sports workers, direct management experience, the 


\begin{tabular}{|c|c|c|c|c|c|c|}
\hline \multirow{4}{*}{ Impact Factor: } & ISRA (India) & $=3.117$ & SIS (USA) & $=0.912$ & ICV (Poland) & $=6.630$ \\
\hline & ISI (Dubai, UAE & $=0.829$ & РИНЦ (Russia & $=0.156$ & PIF (India) & $=1.940$ \\
\hline & GIF (Australia) & $=0.564$ & ESJI (KZ) & $=8.716$ & IBI (India) & $=4.260$ \\
\hline & JIF & $=1.500$ & SJIF (Morocce & $=5.667$ & OAJI (USA) & $=0.350$ \\
\hline
\end{tabular}

availability of vocational education not only in sports, but also of managerial and economic nature and the level of professional skills of a leader, come to the fore. The most significant drawback, in our opinion, is the complete lack of listeners of these refresher courses of personal desire to apply the acquired managerial knowledge in their work, in their organization's work. None of the trainees of the courses takes part in the development, shaping and direct testing of various solutions aimed at improving the work of specialists in the field of PC \& S [10].

\section{Conclusions}

Thus, we found that the professional activity of a sports management specialist abroad is characterized by independence in decision making, teamwork and personal responsibility in carrying out work, which, along with the peculiarities of the necessary competencies and constant changes in the professional environment, places new demands on the preparation of a modern specialist. These requirements should be manifested in the emphasis of training on the compliance of abilities and values of a specialist with the requirements of a professional environment.

The materials obtained will be used in the course of writing a $\mathrm{PhD}$ thesis to identify the process of formation of key competencies in a sports manager in the context of socio-economic transformation.

\section{References:}

1. Bondarenko, M. P. (2013). Formation of the remuneration system of sports trainers. The standard of living of the population of the regions of Russia, No. 8 (186), pp.75-78.

2. Belotserkovets, E. A., \& Karpov, V. Y. (2008). Features of training specialists in the field of physical culture in modern conditions. Physical culture, sport - science and practice, № 93, pp. 51-54.

3. Bondarenko, M. P. (2013). Methods of assessing the competence of sports trainers. The standard of living of the population of the regions of Russia, No 3 (181), pp. 90-92.

4. Bondarenko, M. P., Zubarev, Y. A., \& Ryabenko, G. V. (2013). Evaluation of the marketing effectiveness of sports organizations. Bulletin of the Eurasian Academy of Administrative Sciences, № 2 (23), pp. 62 -66.

5. Kandaurova, N. V. (2014). Organizational, managerial and entrepreneurial activities of the head of a sports school: Dis .... Dr. Ped. sciences. (p.368). Moscow.

6. Karpov, V. Y. (2013). Innovative approaches to teaching the discipline "Theory and methods of physical culture". Social policy and sociology, № 4-1 (96), pp. 49-58.

7. Karpov, V. Y., \& Avgustimova, O. S. (2004). Multi-level system of management education in foreign universities of physical culture // Physical culture and sport in the modern education system: materials of the Vth scientificpractical conference. (pp.146-149). Samara: Publishing house of the State Pedagogical University.
8. Karpov, V. Y., Avgustimova, O. S., \& Eremin, M. V. (2015). A modern view on the training of a sports manager // Image of education - the challenges of the modern world: materials of the First International Conference. (pp.85-90). Ryazan.

9. Karpov, B. Y., et al. (2013). Means of physical culture and sports as a basis for the prevention of drug addiction and bad habits in the adolescent environment. Sochi Journal of Economy, № 1-1, pp.102-109.

10. Yaroshenko, L. V., Karaseva, N. V., \& Tarasenko, A. P. (2004). Activation of selfeducation processes and implementation of the results of advanced training in practice // Additional professional education in the field of physical culture, sports and tourism in the context of modern achievements of science and practice: materials of the All-Russian Scientific Conference / Comp. I.D. Fistulous. (pp.143144). Moscow: SportAkademPress.

11. Zuev, V. N. (2006). Management and managers of the domestic sphere of physical culture and sports: a textboo. (p.400). Moscow: Physical culture.

12. Makhova, I. Y., \& Zenina, R. S. (2006). Psychology of competence: phenomenology, diagnostics and dynamics in the conditions of a Russian university: monograph, p.387.

13. (2006). Contemporary Sport Management. In Janet B. Parks, Jerome Quaterman, Lucie Thibault (Eds.). - 3rd ed., p.508.

14. Patterson, V., \& Allen, C. (1996). Occupational Outlook Overview: Where Will the Jobs Be in 


\begin{tabular}{llllll} 
& ISRA (India) $=\mathbf{3 . 1 1 7}$ & SIS (USA) & $=\mathbf{0 . 9 1 2}$ & ICV (Poland) & $\mathbf{= 6 . 6 3 0}$ \\
Impact Factor: & ISI (Dubai, UAE) $=\mathbf{0 . 8 2 9}$ & PUHЦ (Russia) $=\mathbf{0 . 1 5 6}$ & PIF (India) & $=\mathbf{1 . 9 4 0}$ \\
& GIF (Australia) $=\mathbf{0 . 5 6 4}$ & ESJI (KZ) & $=\mathbf{8 . 7 1 6}$ & IBI (India) & $=\mathbf{4 . 2 6 0}$ \\
JIF & $=\mathbf{1 . 5 0 0}$ & SJIF (Morocco) $=\mathbf{5 . 6 6 7}$ & OAJI (USA) & $\mathbf{0 . 3 5 0}$ \\
\hline
\end{tabular}

2005? Journal of Career Planning and Employment, 56(3), 32-35, 61-64.

15. Pitts, B. G., \& Stotlar, D. K. (2002).

Fundamentals of Sport Marketing (2nd ed.).
Morgantown, WV: Fitness Information Technology. 